\section{Seasonal Variation in Low- temperature Tolerance of Vaccinium angustifolium Ait.}

\author{
Paul E. Cappiello ${ }^{1}$ and Scott W. Dunham ${ }^{2}$ \\ Department of Plant, Soil, and Environmental Sciences, University of Maine, \\ Orono, ME 04469-5722
}

Additional index words. lowbush blueberry, cold hardiness, winter injury, small fruit

\begin{abstract}
Seven Vaccinium angustifolium clones were tested for low-temperature tolerance over two dormant seasons. Flower primordia in the pseudoapical bud were damaged at higher temperatures than were stem tissue and primordia of the fourth floral bud. The flower primordia located at the stem tip also reacclimated earlier and seemed to show a stronger response to abrupt spring warming than did other tissues tested. Given the lowest survival temperatures determined and the ambient temperatures recorded, we recommend that the physiological and economic aspects of cryoprotectants and flower-delaying treatments be studied further.
\end{abstract}

The lowbush blueberry in northeastern North America is a managed wild crop that produces $\approx 20$ million kilograms of fruit each year in Maine alone. The crop is composed mainly of Vaccinium angustifolium, with a minor amount of $V$. myrtilloides Michx. In commercial production, fruit is produced in alternate years. The first year's vegetative growth produces flower buds for the following season's crop; in the second year, the flower buds produce flowers and fruit that is harvested in late summer. There has been an increase in per-acre production of lowbush blueberry over the past two decades as a result of improved pest control and fertility programs. However, the increases in production have been inconsistent from year to year, partially because of problems arising from low-temperature damage. Inconsistent yield is a problem facing growers attempting to enlarge their markets

Low-temperature tolerance of vegetative and reproductive tissues of Vaccinium spp. has been investigated. Hancock et al. (1987) reported significant variation in frost tolerance of flowers of several highbush blueberry (V. corymbosum L.) cultivars. They reported that bud position and stage of flower opening significantly influenced the amount of damage sustained during two spring frosts. Gupton (1983) also reported that frost tolerance of flowers decreased as anthesis progressed in rabbiteye blueberry (V. ashei Reade) cultivars. Patten et al. (1991) compared lowtemperature tolerance of rabbiteye, highbush,

\footnotetext{
Received for publication 26 July 1993. Accepted for publication 27 Oct. 1993. This work was supported by the Maine Blueberry Commission and the Maine Agricultural and Forest Experiment Station; publication no. 1788. The cost of publishing this paper was defrayed in part by the payment of page charges. Under postal regulations, this paper therefore must be hereby marked advertisement solely to indicate this fact.

Assistant Professor.

Crop Technician.
}

and southern highbush blueberry (Vaccinium spp.). Rabbiteye was the most cold sensitive and showed a linear increase in lowtemperature-induced damage with progressive opening of flowers. Using V. corymbosum 'Rancocas', Biermann et al. (1979) reported that bud position on the stem and floret moisture content played important roles in determining lowest survival temperatures (LST) of reproductive tissues during the dormant season. Quamme et al. (1972) found that two $V$. angustifolium clones were significantly more cold hardy than nine other Vaccinium species and hybrids.

We conducted a series of experiments during Winter 1991-92 and 1992-93 to understand better the patterns of low-temperature tolerance in $V$. angustifolium. Our specific goal was to determine the minimum survival temperatures of vegetative and reproductive structures over the dormant season.

\section{Materials and Methods}

For the initial study, four clones of $V$. angustifolium were identified in a commercial production field in Ellsworth, Maine. Beginning in November and continuing through May, 30 stem samples per clone were collected monthly, placed in a cooler on crushed ice, and brought to Orono, Maine, for analysis. Stems collected had an inflorescence bud at each of the top four nodes (positions 1-4, numbered basipetally). Each stem was sealed in a $15-\mathrm{mm}$ glass culture tube before transferring to the freezing apparatus. Samples were not surrounded with a moist medium as in other studies (Lindstrom and Dirr, 1991; Warmund et al., 1989), because an initial test series indicated that the moist medium did not affect LST estimate. All samples were processed as described within 6 hours of harvest.

Prepared samples were placed in a microprocessor-controlled low-temperature freezer (model 40-9.4; Scientemp, Adrian, Mich.) for freeze tests. A nickel-constantan thermocouple was imbedded under the bark of a reference sample for monitoring stem tissue temperatures. The study was conducted using four clones during Winter 1991-92 and on three clones during Winter 1992-93.

Tissue was acclimated in the chamber at $3 \mathrm{C}$ for $\approx 3 \mathrm{~h}$. Then the chamber temperature was decreased to $-3 \mathrm{C}$ over $2 \mathrm{~h}$, held for $\approx 4 \mathrm{~h}$, and decreased again at a rate of $3 \mathrm{C} / \mathrm{h}$ to a minimum of $-40 \mathrm{C}$. Five stem samples of each clone were removed at $5 \mathrm{C}$ intervals from $-5 \mathrm{C}$ to $-40 \mathrm{C}$ and were placed immediately in a chamber held at $3 \mathrm{C}$ for $\approx 24 \mathrm{~h}$. Then they were held at $\approx 24 \mathrm{C}$ for $48 \mathrm{~h}$ before evaluation.

Following cold treatment, samples were sectioned and visually evaluated under a binocular microscope for damage to stem tissue and flower primordia. Inflorescence buds 1-4 and a $1-\mathrm{cm}$ stem segment (located $1 \mathrm{~cm}$ below the stem tip) were sliced longitudinally for evaluation. Stem tissue was evaluated for damage as described by Fuchigami et al. (1971), Sakai et al. (1986), and Lindstrom and Dirr (1991). After $48 \mathrm{~h}$ of incubation at 24C, oxidative browning of phloem and cambial tissues was easily distinguished. Stems exhibiting such signs were classified as dead. The number of stems surviving each temperature treatment was recorded. Flower primordia, visible from a single median section of each flower bud, were counted, and the percent survival was determined. Survival was determined by the absence of browning in the corolla and visible ovaries. As with evaluations of stem tissue damage, the damage to the corolla and ovaries was easily distinguished from healthy tissue in the florets.

Statistical analysis was performed using Duncan's multiple range test (SAS Institute, 1985) $(\alpha=0.05)$, following arcsin transformation of percent survival data. Data are presented in the LST format (Lindstrom and Dirr, 1991; Sakai et al., 1986). The LST designated in this report is the lowest temperature treatment that resulted in $100 \%$ stem or flower primordia survival. Some previous reports on cold hardiness of woody taxa have reported LST based on survival percentages ranging from $40 \%$ to $66 \%$ (Biermann et al., 1979; Pellett et al., 1991; Sakai et al., 1986). For our study, $100 \%$ survival was chosen because it requires less interpolative manipulation of data to estimate the value, and it does not assume linearity of response to the temperature treatments. There was little linearity of response with $V$. angustifolium. Once the chamber temperature decreased to the temperature where damage occurred, there was a rapid drop in survival from one temperature to the next in all cases using $V$. angustifolium clones. As noted in other similar studies (Lindstrom and Dirr 1991), the lack of variability within clones precluded the necessity for any additional statistical analysis. In all cases, the $100 \%$ survival at the LST was significantly different than the survival percentage at the next lowest temperature as determined by Duncan's multiple range test.

\section{Results and Discussion}

A significant seasonal pattern of low- 
temperature tolerance was observed for all clones during both studies (Tables 1-4). There was a significant difference in flower primordia cold tolerance based on bud position on the stem (Table 3). There was also a similar trend

of seasonal low-temperature tolerance exhibited by flower primordia and stem tissue during both test years.

The LST values for the inflorescence bud at position 1 (tip of stem) indicated that all

Table 1. Minimum temperature $\left({ }^{\circ} \mathrm{C}\right)$ resulting in $100 \%$ survival of Vaccinium angustifolum flower primordia of the tip inflorescence bud.

\begin{tabular}{|c|c|c|c|c|c|c|c|c|}
\hline \multirow[b]{2}{*}{ Clone } & \multicolumn{8}{|c|}{ Sampling date } \\
\hline & 12 Nov. & $16 \mathrm{Dec}$. & 17 Jan. & 19 Feb. $^{z}$ & 10 Mar. & 13 Apr. & 23 Apr. & 11 May \\
\hline \multicolumn{9}{|c|}{ 1991-92 Study } \\
\hline 1 & -20 & -20 & -25 & -20 & -20 & -5 & -2 & -2 \\
\hline 2 & -20 & -20 & -25 & -20 & -20 & -5 & -2 & -2 \\
\hline 3 & -20 & -25 & -30 & -30 & -25 & -10 & -2 & -2 \\
\hline 4 & -20 & -20 & -30 & -30 & -30 & -10 & -5 & -5 \\
\hline \multicolumn{9}{|c|}{ 1992-93 Study } \\
\hline 5 & -25 & -25 & -30 & -30 & -25 & -25 & -15 & -5 \\
\hline 6 & -25 & -25 & -30 & -35 & -30 & -25 & -20 & -15 \\
\hline 7 & -20 & -25 & -35 & -35 & -25 & -25 & -15 & -5 \\
\hline
\end{tabular}

${ }^{2}$ Plants covered by snow in Feb.1992 and 1993 and in Mar. 1993.

${ }^{y_{n}}=5$.

${ }^{x} n=3$.

Table 2. Minimum temperature $\left({ }^{\circ} \mathrm{C}\right)$ resulting in $100 \%$ survival ofVaccinium angustifolium flower primordia of the fourth bud.

\begin{tabular}{|c|c|c|c|c|c|c|c|c|}
\hline \multirow[b]{2}{*}{ Clone } & \multicolumn{8}{|c|}{ Sampling date } \\
\hline & 12 Nov. & $16 \mathrm{Dec}$. & $17 \mathrm{Jan}$. & 19 Feb. $^{y}$ & $10 \mathrm{Mar}$. & $13 \mathrm{Apr}$. & 23 Apr. & $11 \mathrm{May}$ \\
\hline \multicolumn{9}{|c|}{ 1991-92 Study $y^{x}$} \\
\hline 1 & -25 & -25 & -30 & -35 & -30 & -25 & -10 & -10 \\
\hline 2 & -25 & -25 & -30 & -35 & -30 & -25 & -15 & -5 \\
\hline 3 & -25 & -30 & -35 & -35 & -35 & -25 & -10 & -10 \\
\hline 4 & -20 & -25 & -30 & -35 & -30 & -25 & -10 & -5 \\
\hline \multicolumn{9}{|c|}{ 1992-93 Study ${ }^{w}$} \\
\hline 5 & $\cdots^{v}$ & -30 & -35 & -35 & -30 & -30 & -20 & -10 \\
\hline 6 & $--^{v}$ & -30 & -35 & -40 & -30 & -30 & -25 & -15 \\
\hline 7 & $--^{v}$ & -25 & -30 & -35 & -30 & -25 & -20 & -10 \\
\hline
\end{tabular}

${ }^{\mathrm{z} B u d} 4$ counting from stem tip.

yPlants covered by snow in Feb. 1992 and 1993 and in Mar.1993.

${ }^{x} n=5$.

${ }^{\mathrm{w}} \mathrm{n}=3$.

'Data not available.

Table 3. Survival percentage for Vaccinium angustifolium flower primordia exposed to $-40 \mathrm{C}$ as affected by bud position. ${ }^{2, Y . X}$

\begin{tabular}{lcccccccc}
\hline Bud & \multicolumn{7}{c}{ Sampling date } \\
position $^{w}$ & 12 Nov. & 16 Dec. & 17 Jan. & 19 Feb. & 10 Mar. & $13 \mathrm{Apr}$. & 23 Apr. & 11 May \\
\hline 1 & $5 \mathrm{a}$ & $25 \mathrm{a}$ & $16 \mathrm{a}$ & $20 \mathrm{a}$ & $4 \mathrm{a}$ & 4 & $0 \mathrm{a}$ & $0 \mathrm{a}$ \\
2 & $6 \mathrm{a}$ & $34 \mathrm{a}$ & $22 \mathrm{~b}$ & $26 \mathrm{a}$ & $10 \mathrm{a}$ & $19 \mathrm{~b}$ & $10 \mathrm{~b}$ & $0 \mathrm{a}$ \\
3 & $35 \mathrm{~b}$ & $45 \mathrm{~b}$ & $41 \mathrm{c}$ & $47 \mathrm{~b}$ & $28 \mathrm{~b}$ & $25 \mathrm{bc}$ & $18 \mathrm{~b}$ & $0 \mathrm{a}$ \\
4 & $-{ }^{v}$ & $64 \mathrm{c}$ & $45 \mathrm{c}$ & $51 \mathrm{~b}$ & $34 \mathrm{~b}$ & $38 \mathrm{c}$ & $31 \mathrm{c}$ & $0 \mathrm{a}$ \\
\hline
\end{tabular}

${ }^{2}$ All data from $1992-93$ study.

yata for all three clones combined.

'Mean separation within columns by Duncan's multiple range test $(\alpha=0.05)$.

"Position 1 = tip bud.

'Data not available.

Table 4. Minimum temperature $\left({ }^{\circ} \mathrm{C}\right)$ resulting in $100 \%$ survival of Vaccinium angustifolium stems.

\begin{tabular}{lcccccccc}
\hline \hline & \multicolumn{7}{c}{ Sampling date } \\
\cline { 2 - 9 } Clone & 12 Nov. & 16 Dec. & 17 Jan. & 19 Feb. & 10 Mar. & 13 Apr. & 23 Apr. & 11 May \\
\hline & & & \multicolumn{7}{c}{$1991-92$ Studyz } \\
1 & -25 & -30 & -40 & $-40^{y}$ & -40 & -35 & -20 & -15 \\
2 & -20 & -30 & -35 & -35 & -30 & -25 & -20 & -15 \\
3 & -25 & -30 & -40 & $-40^{y}$ & -35 & -35 & -20 & -15 \\
4 & -25 & -30 & $-40^{y}$ & $-40^{y}$ & -40 & -35 & -20 & -20 \\
& & & & $1992-93$ Study & & & & \\
5 & -25 & -35 & -35 & -35 & -35 & -30 & -20 & -15 \\
6 & -25 & -35 & -35 & $-40^{y}$ & -35 & -30 & -25 & -15 \\
7 & -20 & -30 & $-40^{y}$ & $-40^{y}$ & -30 & -25 & -20 & -15 \\
\hline
\end{tabular}

${ }_{\mathrm{n}}=5$.

${ }^{y}$ Actual readings less than $-40 \mathrm{C}$.

${ }^{\mathrm{x}} \mathrm{n}=3$. clones reached peak cold hardiness on or around either the January or February sampling dates (Table 1). Of the seven clones tested, two clones ( 1992-93 study) reached an LST of $-35 \mathrm{C}$. In comparison, flower primordia in the fourth bud of all clones were able to withstand $-35 \mathrm{C}$ (Table 2). Fourth flower bud primordia of clone 6 were able to survive $-40 \mathrm{C}$ in Feb. 1993.

For buds in the first position, greatest loss of low-temperature tolerance occurred between the 10 Mar. and 13 Apr. sampling in the 199192 study (Table 1). For all four clones, there was a minimum $15 \mathrm{C}$ increase in the LST between these two sampling dates. This abrupt change in LST was not observed during the 1992-93 study. One explanation for the later, more gradual deacclimation of the clones during 1992-93 is the more moderate warming trend during that spring (Figs. 1 and 2). The rapid rise in minimum and maximum temperatures in mid-Mar. 1991 likely played a role in the change in LST. Several previous studies have indicated that warming stem and floral tissues before low-temperature tolerance testing drastically decreases tolerance. Pellett et al. (1991) showed a positive correlation between minimum survival temperature and daily mean temperatures for the 3 days immediately before testing. They indicated that this short-term dehardening maybe more important than ecotype in determining low-temperature survival in certain Rhododendron species. In addition, Warmund et al. (1989) reported that, after chilling requirements were met and $12 \mathrm{~h}$ of incubation at $16 \mathrm{C}$, Rubus spp. had a significant loss of lowtemperature tolerance. Daily maximum temperatures for the 3 days before the $13 \mathrm{Apr}$. 1992 sampling date were 25.2, 20.7, and 23.8C and followed a record high of $31.2 \mathrm{C}$ ten days earlier (Fig. 1). In addition, there was an $\approx 20 \mathrm{C}$ rise in the temperature minima for that same time. Our study does not permit us to ascertain the independent effects of the elevated day or night temperatures.

Primordia in the fourth bud position showed greatest loss of low-temperature tolerance between the 13 and 23 Apr. 1992 sampling. The delayed loss of low-temperature tolerance indicates that these tissues may be less sensitive to spring temperature fluctuations than primordia in the first bud position. This later deacclimation is consistent with the basipetal opening of inflorescence buds of field-grown plants. Later deacclimation of the more basally located buds occurred to a lesser degree during 1992-93. Again, this likely is due to the more moderate temperature changes exhibited during that spring.

The difference in low-temperature tolerance of floral tissues based on bud position on the stem is evident from the fact that the two buds at the stem tip were significantly less cold hardy than buds 3 and 4 (Table 3 ). Preliminary work on these same clones indicated that bud 4 reaches peak cold hardiness on the stem and that buds located lower on the stem achieve no greater low-temperature tolerance. This trend agrees with the one described by Biermann et al. (1979), who reported that V. corymbosum 
buds showed increasing cold hardiness the lower they were located on the stem.

Throughout the two seasons of the study, stem tissue attained equal or greater low-temperature tolerance than bud tissue in either the first or fourth position on the stem (Table 4). The single exception was in clone 6 on the Feb. 1993 sampling date. Of the seven clones tested, five reached a cold hardiness level below the lower limit of the equipment. Those clones are indicated as having an LST of less than $-40 \mathrm{C}$. LST of the first flower bud primordia equaled that of stem tissue on only four of the 56 clone-sampling date combinations. Those similarities all occurred on the 12 Nov. sampling dates, when the required killing temperature was well below record lows.

Compared to primordia in the fourth bud, stem tissue again attained a greater or equal degree of cold hardiness; however, in this case, $\approx 40 \%$ of the clone-sampling date combi- nations showed the same LST for flower primordia and stem tissue. Stems and buds (in position 4) showed a similar spring deacclimation pattern. Stems of three of the four clones tested during 1991-92 showed a 15C increase in LST rating between 13 and $23 \mathrm{Apr}$. 1992.

Low-temperature-induced midwinter damage to lowbush blueberry is unlikely to occur in any tissues other than reproductive tissue in the topmost bud. Major blueberry growing regions rarely experience temperatures below those indicated as LSTs for stems and buds located in positions 3 and 4 . Thus, other complicating factors, such as moisture and wind, are involved in the injury to those tissues observed in the field for some years.

Our flower primordia data indicate that buds in the top position maybe subjected to temperatures near or below the listed LST. Buds in the fourth position, however, exhib-

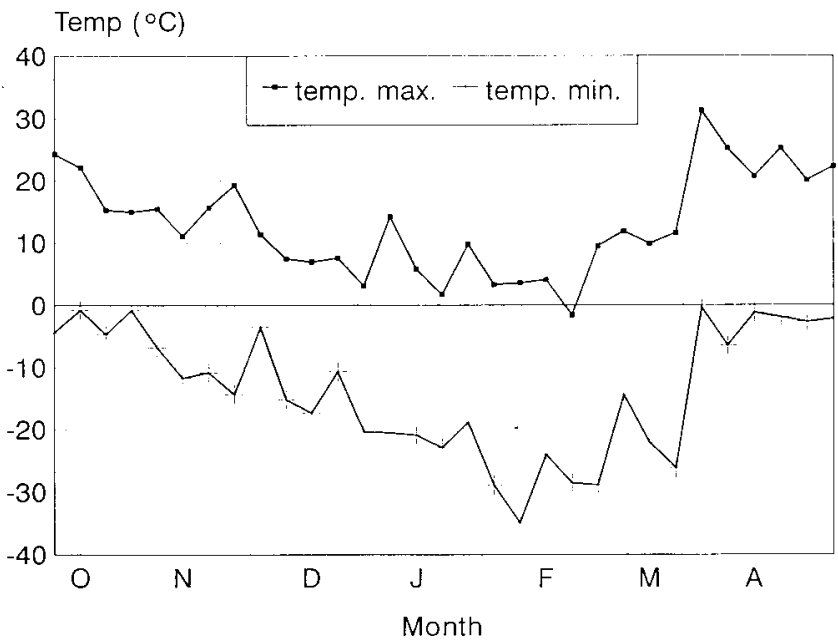

Fig. 1. Weekly minimum and maximum temperatures in 1991-92

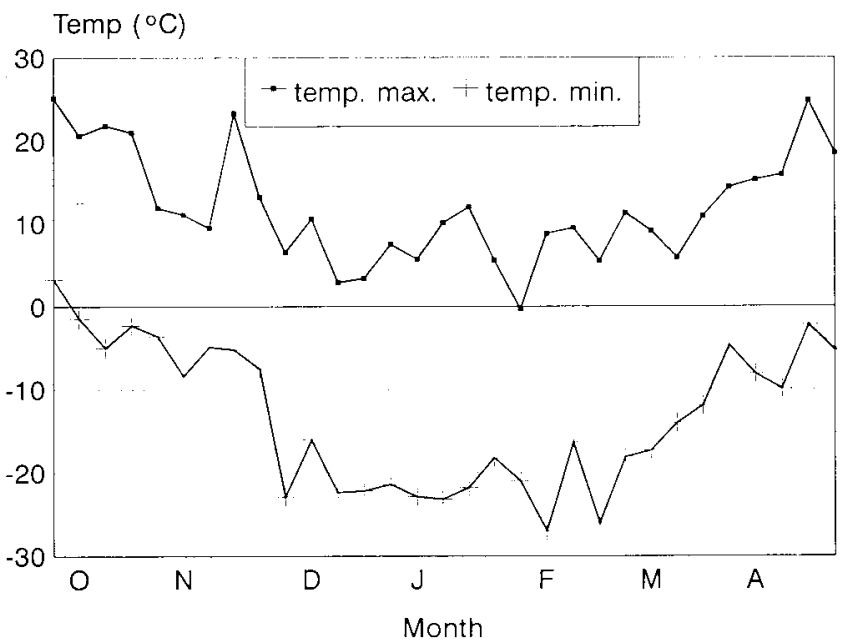

Fig. 2. Weekly minimum and maximum temperatures in 1992-93

ited LSTs below minimum recorded temperatures throughout the studies. Spring field evaluations of the clones indicated no winter injury to buds or stems. This result would be expected for stems and buds in the lower positions because ambient temperatures never dropped below the LSTs. First bud survival at ambient temperatures below the LST likely is due to snow cover. On the two occasions that ambient temperatures dropped below the LST, the plants were covered with snow and, therefore, presumably were insulated sufficiently.

The documented patterns of fall hardening, mid-winter hardiness, and spring dehardening of these tissues will provide a foundation on which to base future studies. Given the LSTs determined and ambient temperatures recorded, we recommend that physiological and economic aspects of cryoprotectants and flower-delaying treatments be studied. Alternatively, selection of clones with greater low-temperature tolerance, delayed spring deacclimation, or both maybe pursued as a solution to low-temperature injury in lowbush blueberry.

\section{Literature Cited}

Biermann, J., C. Stushnoff, and M.J. Burke. 1979. Differential thermal analysis and freezing injury in cold hardy blueberry flower buds. J. Amer. Soc. Hort. Sci. 104:444-449.

Fuchigami, L.H., C.J. Weiser, and D.R. Evert. 1971. Induction of cold acclimation in Cornus stolonifera Michx. Plant Physiol. 47:98-103.

Gupton, C.L. 1983. Variability among rabbiteye blueberry cultivars for tolerance of flowers to frost. HortScience 18:713-714.

Hancock, J.F., J.W. Nelson, H.C. Bittenbender, P.W. Callow, J.S, Cameron, S.L. Krebs, M.P. Pritts, and C.M. Schumann. 1987. Variation among highbush blueberry cultivars in susceptibility to spring frost. J. Amer. Soc. Hort. Sci. 112:702-706.

Lindstrom, O.M. and M.A. Dirr. 1991. Cold hardiness of six cultivars of Chinese elm. HortScience 26:290-292.

Patten, K., E. Neuendorff, G. Nimr, J.R. Clark, and G. Fernandez. 1991. Cold injury of southern blueberries as a function of germplasm and season of flower bud development. HortScience 26:18-20.

Pellett, N.E., N. Rowan, and J. Aleong. 1991. Cold hardiness of various provenances of flame, roseshell, and swamp azaleas. J. Amer. Soc. Hort. Sci. 116:23-26.

Quamme, H.A., C. Stushnoff, and C.J. Weiser. 1972. Winter hardiness of several blueberry species and cultivars in Minnesota. HortScience 7:500-502.

Sakai, A., L. Fuchigami, and C.J. Weiser. 1986. Cold hardiness in the genus Rhododendron. J. Amer. Soc. Hort. Sci, 111:272-280.

SAS Institute, 1985. SAS users guide: Statistics. Version 5 ed. SAS Institute, Cary, N.C.

Warmund, M.R., M.F. George, M.R. Ellersieck, and J.V. Slater. 1989. Susceptibility of blackberry tissues to freezing injury after exposure to $16 \mathrm{C}$. J. Amer. Soc. Hort. Sci. 114:795-800. 